\title{
Effect of type of binder on growth, digestibility, and energetic balance of Octopus maya
}

\author{
Carlos Rosas ${ }^{a,}{ }^{*}$, Julia Tut ${ }^{b}$, Julieta Baeza ${ }^{b}$, Ariadna Sánchez ${ }^{a}$, Vianey Sosa ${ }^{a}$, Cristina \\ Pascual $^{a}$, Leticia Arena ${ }^{a}$, Pedro Domingues ${ }^{c}$ and Gerard Cuzon ${ }^{d}$
}

\footnotetext{
a Unidad Multidisciplinaria de Docencia e Investigación, Facultad de Ciencias, Universidad Nacional Autónoma de México, Puerto de abrigo s/n, Sisal C.P.97350, Hunucmá, Yucatán, Mexico

${ }^{\mathrm{b}}$ Instituto tecnológico de Conkal, Yucatán, Mexico

${ }^{c}$ Centro IFAPA, Agua del Pino, Carretera Punta Umbría-Cartaya s/n, 21450, Cartaza, Spain

d IFREMER, Tahiti, French Polynesia
}

*: Corresponding author : Carlos Rosas, email address : crv@hp.fciencias.unam.mx

\begin{abstract}
:
The present study was designed to test the effects of type of binder on growth, nutritional physiology, total apparent digestibility, and some elements of the energetic balance of early $\mathrm{O}$. maya juveniles. Two experiments were performed. One was aimed at evaluating the effect of type of binder on growth, nutritional physiology, and energetic balance and the other at knowing the effect of the binder on total apparent digestibility of $\mathrm{O}$. maya. Binder type affected growth and survival of early $\mathrm{O}$. maya juveniles. Octopuses fed alginate-bound crab meat lost weight and died, revealing that this type of binder limits nutrient absorption from the diet. In contrast, when gelatin was used as binder, energetic balance was similar to that obtained in animals fed natural crab, indicating that octopuses can digest gelatin. Apparently, gelatin promotes absorption of nutrients similar to that observed when octopuses were fed pieces of fresh crab. Salivary glands produce enzymes that are used to predigest the food. Results of the present study indicate that octopuses require higher enzyme activity to digest fresh crab than when animals are fed gelatin-bound crab paste, and that intracellular digestion in the digestive gland is similar in animals fed either type of diet. The present study reports, for the first time, differences among binders used for cephalopods' diet. Although no compounded feed formulations are available for cephalopods, it is a necessary step in the search for an adequate compounded feed for this novel species in aquaculture.
\end{abstract}

Keywords: Octopus maya; Digestibility; Diet binder; Energetic balance; Growth rate 


\section{Introduction}

Binders are used to improve feed manufacture and to stabilize diets in water. Lignosulfonates, cellulose, carboxymethylcellulose (CMC), corn starch, wheat starch, arabic gum, polymers, among others, are used as binders (Yamamoto and Akiyama, 1995). The problem of feed stability is far more crucial with shrimp than it is with fish. With fish, for example, binders can be included in practical diets, however commercial feeds tend to be stable only after extrusion. Some experiments have been reported on the incorporation level of alginate used to bind feed or to get firmer feces when emitted into the water to reduce pollution (Cho and Bureau, 2001; Brinker et al., 2005). In the case of alginate, several reports indicate a relation with the digestibility of nutrients (Storebakken, 1985; Morales et al., 1993; Arzel et al., 1995). In sea bass, a negative effect of alginate has been shown when a higher than $15 \%$ inclusion was used (Gabaudan, 1987). In contrast, shrimp cannot tolerate a feed that disintegrates in a few min; hence, binders play a key role in feeding. Some binders, such as wheat gluten, possess the double quality of stabilizing the feed with a reticulum that holds particles together and has nutritional value. At a commercial level, there were some polymers used in the 80's to firmly bind the feed mixture through a reaction between the $-\mathrm{NH}_{2}$ terminal of the protein and the polymer. This reaction had an effect on protein digestibility, especially when the level exceeded $1 \%$. Aside from polymers, most binders, such as bentonite, $\mathrm{CMC}$, lignosulfonates have little affect on feed digestibility, even though only limited information exists.

Energetic balance studies have been used as a tool for monitoring the form in which a diet modulates the ingested energy in cephalopods (Petza et al., 2006). Recent studies have attempted to substitute fresh crab by a balanced diet for $O$. maya. In the first study, a commercial pelleted diet enriched with squid paste was compared to a fresh crab diet. Results showed that the high lipid levels (21\%) in the pelleted diet limited the digestibility of the rest of nutrients, producing a negative growth response (Domingues et al., 2007). A second pelleted diet was designed a with low lipid level and following the chemical profile of crab meat. Two protein levels were assayed ( 40 and $60 \%$ $\mathrm{CP})$ in an attempt to reach the protein level of crab (56\% CP). Only marginal growth was obtained in octopuses fed $60 \%$ CP $\left(0.08 \%\right.$ day $\left.^{-1}\right)$ indicating that some other element(s), aside from lipid, interfered with biomass accumulation and digestible energy ( $\mathrm{DE}=8 \%$ of ingested energy). Digestive enzymes (generally, proteases such as trypsin) were induced, suggesting that a diet with high protein level regulated Octopus digestion, we also observed that DE of the diet had a limit at $50 \%$ of ingested energy (Aguila et al., 2007). In an attempt to improve protein quality, five diets with different hydrolyzed fish protein levels $\left(\mathrm{CPSP}^{80}\right)$ were tested. Although improved growth was observed in octopuses fed $15 \%$ CPSP $^{80}$ with $0.7 \%$ day $^{-1}$, it remained lower than in octopuses fed fresh crab with $4 \%$ day $^{-1}$ (Rosas et al., 2007). Essential amino acids (EAA) in all the experimental diets were higher than in Octopus EAA profile, suggesting some other element(s) limited the digestibility of a formulated diet in this species (DE $=41 \%$ in octopuses fed $15 \% \mathrm{CPSP}^{80}$ ). A high and constant DE (82\%) was observed with octopuses fed fresh crab.

When octopuses are fed, the posterior salivary gland delivers enzymes to produce an extracellular digestion. Plenty of digestive enzymes (mainly chymotrypsin) pass through the esophagus and stomach, where enzymes from the digestive gland complete the digestion. Once molecules pass to the digestive gland, nutrient absorption and assimilation starts (BoucaudCamou, 1969, 1974; Bouche-Rodoni, 1975; Boucaud-Camou et al., 1976). Studies conducted in O. maya and other cephalopods have shown that digestive enzymes are mainly proteases, indicating that the type of ingredients to be used to formulate an Octopus feed must have enough quality protein to facilitate digestion. Alginate used as a binder of experimental diets for $O$. maya could interfere with digestion of this octopus species. The main reason is that octopuses have a very low carbohydrases activity that could limit the digestion of alginate (Aguila, 2007). Therefore, the present study was designed to test the effect of type of binder on growth, nutritional physiology, apparent digestibility, and on some elements of the energetic balance for early juveniles of $O$. maya. 


\section{Material and methods}

Two experiments were completed. One was aimed at evaluating the effect of type of binder on growth, nutritional physiology, and energetic balance and the second to determine the effect of the binder on apparent digestibility of $O$. maya.

\subsection{First experiment}

\subsubsection{Animals}

Early octopus juveniles (O. maya) were obtained from hatchlings spawned under controlled conditions. Wild females were acclimated to the maturation area of the National University of Mexico (UNAM) located in Sisal, Yucatan, Mexico. Hatchlings were fed for 15-20 days with live adult Artemia and Palaemonete juveniles until they exceeded $0.5 \mathrm{~g}$ live weight. Afterward, 60 octopuses were distributed into three groups. Animals were placed individually in $500-\mathrm{mL}$ tanks connected to a flow-through seawater system. All animals were weighed at the beginning of the experiment $( \pm 0.005 \mathrm{~g})$ and assigned randomly to tanks. Each tank was provided with a clean Megalongena corona bispinosa conch to serve as a refuge. Tanks were covered with a plastic cap to avoid octopuses from escaping. The seawater system was aerated in a 1500-L external tank as to maintain oxygen levels in each chamber above $5 \mathrm{mg} / \mathrm{L}$. Temperature of individual tanks was maintained by controlling temperature of the external tank using a titanium heater/ chiller.

\subsubsection{Diets}

Animals were fed a fresh crab meat paste (Callinectes sapidus) bound with alginate (1\% sodium alginate) or $2 \%$ gelatin. Natural fresh crab meat (fragments of muscle attached to the exoskeleton) were used as the control diet. All diets were fed ad libitum (40\% of biomass) for 20 days. All diets (pastes and crab meat) were prepared weekly.

\subsubsection{Growth rate}

Octopuses were individually weighed at the beginning and end of the experimental period. Growth was determined as the difference between weights at the start and end of the experiment. Daily growth coefficient (DGC, \%day ${ }^{-1}$ ) was determined as:

$\mathrm{DGC}=\left[\left(\mathrm{LnW}_{2}-\mathrm{LnW}_{1}\right) / \mathrm{t}\right]^{\star} 100$

where, $W_{2}$ and $W_{1}$ are the final and initial wet weights of the octopuses, Ln the natural log, and $t$ the number of experimental days (20).

\subsubsection{Digestive enzyme activity}

Enzymatic activity was measured individually in octopuses at the end of the 20 day feeding period. Enzymatic activity of animals fed alginate-bound crab meat was not determined due to the high mortality observed in octopus fed this diet.

Salivary (posterior) and digestive glands were dissected and stored at $-40^{\circ} \mathrm{C}$ until assayed. All animals were fasted $12 \mathrm{~h}$ before sampling. Frozen samples were homogenized at $4^{\circ} \mathrm{C}$ in $500 \mu \mathrm{L}$ ice-cold pyrogen-free water. Homogenates were centrifuged at $13200 \mathrm{rpm}$ (change to $\mathrm{x} \mathrm{g}$ ) for $20 \mathrm{~min}$ at $4^{\circ} \mathrm{C}$. The supernatant was diluted in 10 volumes of ice-cold pyrogen-free water. Homogenates were immediately used for enzyme assays. The soluble-protein content was measured in diluted homogenates (Bradford, 1976) using the Bio-Rad protein determination kit (Biorad $\left.{ }^{@}-500-0006\right)$. 
Samples were read in a Biorad model 550 microplate reader at $495 \mathrm{~nm}$. All assays were run in duplicate. General proteases activity was measured in homogenates using azocoll (Sigma A-4341) as substrate in phosphate buffer, $\mathrm{pH}$ 7. Absorbance was read with a spectrophotometer (Spectronic model 21D) at $520 \mathrm{~nm}$. One unit is defined as the amount of enzyme that catalyzes the release of azo dye causing a $\Delta \mathrm{A} / \Delta \mathrm{t}=0.001 \mathrm{~min}^{-1}$. Trypsin activity was measured in diluted (1:100) homogenates using benzoil-arginine-para-nitro-anilide (100 mM BAPNAl) as substrate in a buffer (0.1M TRIS, $0.05 \mathrm{M} \mathrm{NaCl}, \mathrm{pH} 7.5)$ at $4^{\circ} \mathrm{C}$. Absorbance was read at $405 \mathrm{~nm}$. Leucine aminopeptidase (Leu- amino peptidase) was measured in diluted (1:10) homogenates using $100 \mathrm{mM} \mathrm{L}$ leucine- p-nitro-anilide (LPNA) as substrate in a buffer (0.1M TRIS, $\mathrm{pH} 8)$ at $25^{\circ} \mathrm{C}$. Absorbance was read at $410 \mathrm{~nm}$.

\subsubsection{Glutamate dehydrogenase (GDH) activity}

Gills from experimental octopuses were immediately dissected and quickly frozen in liquid nitrogen, then stored at $-40{ }^{\circ} \mathrm{C}$ for subsequent analysis. Enzyme assays were performed individually on crude homogenates of gill tissue (Regnault, 1979). Conditions for these assays were $50 \mathrm{mM}$ imidazole $\mathrm{HCl}$ buffer, $\mathrm{pH}$ 8.0, made with $0.5 \mathrm{mM}$ PMFS, $5 \mathrm{mM}$ mercapthoethanol, and $750 \mathrm{mM}$ ammonium acetate. We used $40 \mu \mathrm{L}$ gill extract and $155 \mathrm{mM} \alpha$-ketoglutarate (final volume $=1 \mathrm{~mL}$ ). Enzyme activity was determined from the slope $\left(\mathrm{V}^{\circ}\right)$ of $\mathrm{NADH}$ oxidation recorded at $320 \mathrm{~nm}(\varepsilon=$ $6.22 \times 10^{-3}$ ) at room temperature. The soluble-protein content was measured in diluted homogenates (Bradford, 1976) using the Bio-Rad protein determination kit (Biorad ${ }^{\circledR}$-500-0006) Results are expressed as mIU ( $\mu$ mole NADH formed $\mathrm{min}^{-1} \mathrm{mg}^{-1}$ protein).

\subsubsection{Muscle glycogen and total lipid}

After measuring total weight, muscle tissue was homogenized at $4^{\circ} \mathrm{C}$ for $5 \mathrm{~min}$. Muscle glycogen was extracted in the presence of sulfuric acid and phenol (Dubois et al., 1965). Tissues were first homogenized in ice-cold trichloroacetic acid (TCA, 5\%) at 3,340 g. After centrifugation, the supernatant was quantified; this procedure was done twice. One $\mathrm{mL}$ of supernatant was mixed with 5 volumes of $95 \%$ ethanol. Tubes were placed in an oven at 37 to $40^{\circ} \mathrm{C}$ for $3 \mathrm{~h}$. After precipitation, the tubes were centrifuged at $7000 \mathrm{~g}$ for $15 \mathrm{~min}$. The glycogen pellet was dissolved by adding 0.5 $\mathrm{mL}$ of boiling water. Then, $5 \mathrm{~mL}$ of concentrated sulfuric acid and phenol (5\%) were added and mixed. Tube contents were transferred to micro plates and read at $490 \mathrm{~nm}$ in a micro plate reader (Bio-Rad 550). Extraction of total lipids followed the method of Bligh and Dyer (1959). After phase equilibration, the lower chloroform layer (total lipid) was removed, concentrated, and weighed. Total lipids are expressed as $\mathrm{mg}$ lipid /g of fresh tissue.

\subsubsection{Energetic balance}

Feed intake was calculated as the difference between the fed and remaining diet after $4 \mathrm{~h}$, corrected for the percentage of leached diet. The leaching percentage of the paste diets and fresh crab was measured using the shaking method of Obaldo et al. (2002). For this, $1 \mathrm{~g}$ of diet in 250-mL flasks was shaken in a horizontal shaker at $25^{\circ} \mathrm{C}$ for $2 \mathrm{~h}$. After $2 \mathrm{~h}$, the water was filtered through a Whatman filter number $3(5 \mu \mathrm{m})$ to separate the remaining diet from the leaching water. The leached and original diet samples were dried in a convection oven at $105^{\circ} \mathrm{C}$ for $24 \mathrm{~h}$, and then cooled in a desiccator. Dried diet samples were weighed and analyzed for dry matter retention. Diet stability was calculated as the ratio of dry matter retention after leaching and dry matter of the original samples, expressed as a percentage.

The effect of diet on the physiological condition was measured in 9 animals for each diet. Octopuses were placed in individual respirometry chambers $(150 \mathrm{~mL})$ to measure oxygen consumption and nitrogen excretion. Animals were deprived of food for $12 \mathrm{~h}$ and placed individually 
in respirometry chambers. Chambers were sealed and connected to a flow-through seawater recirculation system (Rosas et al., 1993). To prevent handling stress affecting readings, octopuses were conditioned in the chambers for $12 \mathrm{~h}$ before any readings. Oxygen consumption was calculated as the difference in concentration of dissolved oxygen between the input and output of each chamber, timing the water flow. Dissolved oxygen was measured using a polarographic electrode of a digital oxygen meter (YSI $\left.50 \mathrm{~B} \pm 0.01 \mathrm{mg} \mathrm{L}^{-1}\right)$. The readings were corrected with respect to the control chamber, without octopuses. Oxygen consumption was obtained every $h$ (between 09:30 to 18:30 h). Animals were fed after the first (09:30 h) oxygen consumption measurement. Animals in the control chamber were fed the frozen crab or crab paste diets, using a ration of between 7 to $10 \%$ wet weight $(\mathrm{ww}) \mathrm{d}^{-1}$. At the end of the oxygen consumption measurements, the octopuses were weighed. Routine metabolism ( $\left.\mathrm{R}_{\text {rout }}\right)$ was estimated as $\mathrm{VO}_{2}(\mathrm{mg}$ $\left.\mathrm{g}^{-1} \mathrm{~h}^{-1}\right)$ of unfed octopuses. Apparent heat increment $\left(\mathrm{R}_{\mathrm{AHI}} ; \mathrm{J} \mathrm{g}^{-1} \mathrm{~h}^{-1}\right)$ was estimated from the difference between $\mathrm{VO}_{2}$ of unfed octopuses and the maximum value attained after feeding. A conversion factor of oxygen consumption of $14.3 \mathrm{~J} \mathrm{mg}^{-1}$ was used to transform unfed and fed $\mathrm{VO}_{2}$ to $\mathrm{J} \mathrm{g}^{-1}$ ww (Lucas, 1993). Respiration (Rtot) was calculated as $R_{\text {rout }}+R_{A H I}$ and expressed as $\mathrm{J} \mathrm{d}^{-1} \mathrm{~g}^{-1}$ ww taking into consideration that the octopuses were fed twice a day during the growth trial.

Nitrogen excretion was measured before and after feeding, at the same time as oxygen consumption. Ammonia concentration was analyzed using the colorimetric indophenol method (APHA, 1995). The $U$ values were obtained transforming ammonia values using the $20.5 \mathrm{~J} \mathrm{mg}^{-1}$ value of ammonia excretion (Lucas, 1993). The atomic O:N ratio was estimated for fasting and fed animals, and the recorded values of oxygen consumption and ammonia excretion was transformed to $\mu \mathrm{atg} / \mathrm{h} / \mathrm{g} \mathrm{dw}$. Fed O:N was obtained using the maximum oxygen consumption and nitrogen excretion during the experimental period.

Energy produced $(P)$ was calculated using the actual growth rate of the octopuses obtained during the feeding trial (20 days). The value of $10.1 \pm 1.3 \mathrm{~kJ} \mathrm{~g}^{-1} \mathrm{dw}$ was used to transform the growth data into production units $\left(\mathrm{P} ; \mathrm{J} \mathrm{day}^{-1} \mathrm{~g}^{-1}\right.$ live wt). This value was obtained from analyzing energy content applied to 25 octopuses by means of a calorimeter $\left(\mathrm{Parr}^{\circledR}\right)$, previously calibrated with benzoic acid. Digestible energy (DE) was calculated as: $(U E+Z E)+R_{\text {tot }}+U_{\text {tot }}+P$.

\subsection{Second experiment}

This experiment was performed in an attempt to measure the ADC (apparent digestible coefficient) of gelatin and alginate for $O$. maya. Wild juveniles of $350 \pm 22 \mathrm{~g}(\mathrm{~N}=30)$ live weight were acclimated in 80-L tanks for 15 days before making any measurement. Each tank was connected to a flowthrough seawater system. Octopuses were randomly distributed into three groups. One group was fed crab paste bound with gelatin, the second group was fed crab paste bound with alginate, and the third group was fed crab meat. A ration of $5 \%$ of body weight was delivered per tank. Celite $\left(\right.$ Sigma $\left.^{\circledR}\right)$ was used as a marker and ADC for dry matter was measured (Cuzon and Aquacop, 1998):

$\mathrm{ADC}_{\mathrm{DM}}(\%)=100 \times[1-(\%$ marker in diet/\% marker in feces) $]$

Acid-insoluble ash in feed and feces was measured by burning samples at $500^{\circ} \mathrm{C}$ for $6 \mathrm{~h}$. The ash was placed in boiling $2 \mathrm{~N} \mathrm{HCl}$ for 20 min and filtered through a low fiber filter (Whatman ${ }^{\circledR} 42$ ). Filters were burned in a muffle furnace at $500^{\circ} \mathrm{C}$ overnight. $\mathrm{F}_{\mathrm{AIA}}$ and $\mathrm{Fe}_{\mathrm{AIA}}$ were calculated as:

Acid insoluble ash $(\mathrm{AIA}, \%)=[$ Ash of the sample/dry weight of the sample] $\times 100$

Feces were harvested every day for 10 days, $6 \mathrm{~h}$ after feeding. Feces were washed with distilled water and stored at $-80^{\circ} \mathrm{C}$ until analysis.

\subsection{Statistical analysis}

One way ANOVAs were applied to growth, survival, and energetic balance data. Two way ANOVAs were applied to enzyme activity, glycogen, total lipid, and energy content data to determine the effect of diet on each analyzed tissue. An arc-sine transformation was used before processing percentage data (Zar, 1974). 


\section{Results}

\subsection{First experiment}

Growth rate (DGC;\%) of early juveniles was affected by type of binder (Fig. 1). Octopuses fed alginate-bound crab showed a negative DGC;\% rate. In contrast, octopuses fed crab and gelatin and fresh crab showed positive DGC\% but the difference was not statistically significant $(P>0.05$; Fig. 1). Survival was also affected by type of binder. After the experimental period, only $15 \%$ survival was observed in animals fed alginate-bound crab, whereas 85 and $90 \%$ survival were observed in animals fed the crab-gelatin and fresh crab diets, respectively. Due to the low number and size of octopuses remaining in the groups fed the alginate-bound crab diet, enzymatic activity and energy balance evaluations were done only in animals fed gelatin-bound crab and fresh crab diets.

General proteases showed higher activity in the posterior salivary glands than in the digestive gland for animals fed the gelatin-bound crab and fresh crab diets $(P<0.05$; Fig. 2a). Posterior salivary gland general proteases were higher in animals fed fresh crab than those fed gelatin-bound crab $(P$ $<0.05)$. There were no statistical differences between type of diet on digestive gland general proteases activity. Trypsin activity in the digestive and posterior salivary glands was higher in octopuses fed gelatin-bound crab than in those fed fresh crab (Fig. 2b; $\mathrm{P}<0.05$ ). Type of diet did not affect Leu-amino peptidase activity in the posterior salivary or digestive gland (Fig. 2c). Lower Leu-amino peptidase activity was recorded in digestive glands of octopuses fed fresh crab $(P<$ $0.05)$. GDH activity in gills was four-times higher in octopuses fed gelatin-bound crab than that in animals fed fresh crab (Fig. 3; P $<0.05$ ).

\subsection{Muscle total lipids and glycogen}

Similar values of muscle total lipid and glycogen were obtained from octopuses fed fresh crab and gelatin-bound crab. Mean values of $23.6 \pm 8$ and $0.19 \pm 0.05 \mathrm{mg} /$ tissue of total lipid and glycogen were obtained, respectively.

\subsection{Energy balance}

Feed intake was not affected by diet composition. A mean value of $72.5 \mathrm{mg} \mathrm{g}^{-1}$ was calculated for both types of diet. This value represented a feed intake value of $7.3 \%$ body weight and was calculated for octopuses around $1 \mathrm{~g}$ live weight. An energy intake value of $731.5 \mathrm{~J} \mathrm{day}^{-1} \mathrm{~g}^{-1} \mathrm{ww}$ was found (Table 1).

Octopus oxygen consumption was affected by type of diet. A $41 \%$ higher routine oxygen consumption was obtained for octopuses fed gelatin-bound crab paste than that in animals fed fresh crab (Table 1; $\mathrm{P}<0.05$ ). After the fasting period, octopuses were fed fresh crab or the gelatinbound crab paste at 09:30 h. In both cases, oxygen consumption increased $(P<0.05) 1 \mathrm{~h}$ after feeding, and reached a peak at 10:30 h (Fig. 4). In animals fed fresh crab or gelatin-bound crab paste, oxygen consumption after feeding was 63 and $71 \%$ higher, respectively $(P<0.05)$, than that obtained before feeding. Apparent heat increment (AHI) of octopuses fed gelatin-bound crab paste resulted in a 1.76-times higher value than that observed in animals fed fresh crab (Table 1; P < 0.05). Total respiration $\left(R_{\text {tot }}\right)$ value was $43 \%$ higher in octopuses fed gelatin-bound crab paste than in those fed fresh crab. $R_{\text {tot }}$ corresponded to 15 and $28 \%$ of energy intake from fresh crab and gelatin-bound crab paste, respectively.

Routine ammonia excretion was not affected by the type of diet. A mean value of $0.17 \mathrm{mg} \mathrm{NH}_{3} \mathrm{~h}^{1} \mathrm{~g}^{1}$ ww was calculated (Table 1). An increment in ammonia excretion was recorded $1 \mathrm{~h}$ after feeding in octopuses fed fresh crab and $2 \mathrm{~h}$ after feeding when animals were fed gelatin-bound crab paste (Fig. 5). In both groups, post-prandial ammonia excretion was 2.26 and 3.36 times higher than during fasting for fresh crab and gelatin-bound crab paste diets, respectively $(P<0.05)$. Energy loss through nitrogen products $\left(U_{\text {tot }}\right)$ was 1.39-times higher in animals fed gelatin-bound crab paste than in those fed fresh crab $(P<0.05)$. These values corresponded to 10 and $14 \%$ of energy intake derived from fresh crab and gelatin-bound crab paste, respectively. Fasting and feeding O:N ratios 
of both experimental diets showed values between 2.19 and 3.03, both within the range that indicates protein being metabolized (Table 1). Production $(P)$ was not affected by type of diet. A mean value of $309 \mathrm{~J} \mathrm{day}^{-1} \mathrm{~g}^{-1}$ ww was obtained for early juveniles of $O$. maya. This value corresponded to $42 \%$ energy intake. A mean daily growth coefficient of $1.81 \%$ day $^{-1}$ was calculated.

\subsection{Second experiment}

$A D C_{d m}$ was affected by type of diet (Fig. 6). Octopuses fed alginate-bound crab showed a lower $A D C_{d m}$ value (40.5\%) than animals fed gelatin-bound crab paste $(79 \%)$ or fresh crab $(82 \%)$.

\section{Discussion}

In the present study, the type of binder affected growth rate and survival of early $O$. maya juveniles. Octopuses fed alginate-bound crab meat lost weight and died, showing that this type of binder limited nutrient(s) absorption from the diet. Alginate is a common binder in fish and shrimp diets that has been shown to be quite effective (Dominy et al., 2004). Although a marginal amylolytic activity has been detected in several cephalopod species (Boucaud-Camou and Boucher-Rodoni, 1983), in O. maya, it was not enough to hydrolyze alginate when used as a binder. In fact, amylolytic activity of $O$. maya digestive gland is negligible (Aguila, 2007). Octopuses fed a diet with gelatin as a binder exhibited growth, survival, digestive physiology, and energetic balance data similar to those obtained in animals fed fresh crab. These results indicate that octopuses can digest gelatin adequately, allowing for nutrient absorption at a similar level to that observed when octopuses are fed fresh crab pieces. In cephalopods, salivary and digestive glands are the most important sites for enzymes production and the caecum is the site where chymo-enzymes are absorbed by the digestive gland for intracellular digestion (Boucaud-Camou, 1974; Boucaud-Camou et al., 1976). Food ingestion is the result of a complex procedure involving combination of mechanical and chemical actions in salivary glands (Boucher-Rodoni et al., 1987). Salivary glands produce enzymes that are used to predigest the food. Results of the present study indicate that octopuses require a high enzyme activity to digest fresh crab; this was reflected in a high total proteases activity in the salivary glands. Lower enzyme activity was present in salivary glands of octopuses fed gelatin-bound crab paste indicating that less enzyme activity is required to predigest this type of food. Digestion within the digestive gland was similar in animals fed both types of diet, indicating that, at the end of the digestive process, nutrients were absorbed and mobilized in a similar way. Similar results have been reported for $S$. officinalis showing that this type of behavior could be generalized for other cephalopod species (Perrin et al., 2004)

Animals fed fresh crab or gelatin-bound crab paste were evaluated in regard to their ingestion rate and similar feed intake was observed. The mean value of $7.3 \%$ BW per day for $1 \mathrm{~g}$ octopuses fed either type of diet was similar to that observed in $450 \mathrm{~g}$ (7\% BW per day) O. maya fed frozen crab (Domingues et al., 2007). Octopuses fed crustacea have resulted in similar feed intake values: for example, 9.2\% BW per day for Enteroctopus megalocyathus fed various crab species (Pérez et al., 2006) or 6 to 8\% BW per day for Sepia officinalis fed frozen shrimp (Castro et al., 1993).

A lower level of oxygen consumption and ammonia excretion was observed in octopuses fed fresh crab than in animals fed gelatin-bound crab paste. These results could be useful in terms of the cost involved in feed processing. Octopuses fed gelatin-bound crab paste used 2.5-times more energy as $R_{\mathrm{AHI}}$, and 1.76-times more energy as $R_{\text {tot }}$ than octopuses fed fresh crab. In addition, octopuses fed gelatin-bound crab paste lost 1.3-times more energy as $U_{\text {total }}$ than when fed fresh crab; it was concluded that animals fed crab paste invested more energy to hydrolyze food. In fact, an increase in enzyme activity was observed in animals fed the gelatin-bound paste showing that some biochemical pathways were enhanced by the gelatin-bound paste in these octopuses. Differences in energy balance associated with diet composition have been observed in other octopus species. E. megalocyathus invested $89.6 \%$ in metabolism when fed mussels as compared to $29 \%$ when fed crabs (Pérez et al. 2006). Similarly, a low proportion of energy (26\%) was channeled into biomass production in O. vulgaris fed high lipid diets (Petza et al., 2006). This agrees with data on energy channeled into production, metabolized energy or lost energy reported for other octopus species. In 
E. megalocyathus fed crustacea, metabolic losses accounted for 29\% (Pérez et al., 2006), whereas in young $O$. cyanea fed ad libitum on crabs, production accounted for $57 \%$ of energy intake (Van Heukelem, 1976). Both values are similar to values obtained in the present study for O. maya with metabolic losses (26\%) and production (42\%) of energy intake.

In the present study, lower GDH activity was observed in octopuses fed fresh crab than in those fed gelatin-bound crab paste. In fact, octopuses fed gelatin-bound crab paste produced higher ammonia excretion values than animals fed fresh crab. Gelatin enhanced amino acid catabolism. GDH activity has been related with amino acids catabolism and, in consequence, with ammonia production (Regnault, 1979; Dall and Smith, 1986; Alcaraz et al., 1999). Although both type of diets had similar digestibility values, gelatin is a source of non- essential amino acids, some of which are important energetically in cephalopods and, consequently, in ammonia production. Proline represents $12 \%$ of the amino acids in gelatin and plays an important role in oxidative metabolism of O. vulgaris (Villanueva et al., 2004), whereas arginine with $8 \%$ of the amino acids in gelatin is a precursor of octopine, a compound involved in anaerobic metabolism of cephalopods (Akagi and Ohmori, 2004; Fujisawa et al., 2005).

ADC $D M$ was measured in $O$. maya and no difference was found between octopuses fed gelatinbound crab or fresh crab (79 and $82 \%$, respectively). However, when octopuses were fed alginatebound crab paste, a strong reduction in ADC DM was observed (40.5\%), indicating that alginate interfered with the digestive process in $O$. maya. Alginate is an algal polysaccharide that cannot be digested by $O$. maya due to a lack of amylase enzyme or to an undetectable activity of this enzyme (Águila, 2007). Observations made during fecal collection supported the analytical data and confirmed abundant feces-forming, much more than octopuses fed either fresh crab or gelatinbound crab paste. Although no studies have been reported determining the optimum level of gelatin to be included in a formulated diet, a proportion of 5 to $7 \%$ may be acceptable, because these levels of gelatin have been used in experimental diets in our research laboratory with reasonable success.

\section{Acknowledgments}

The present study was partially financed by DGAPA-UNAM project No. IN 216006-3 and CONACYT-Básico 2007-24743. Thanks are given to Claudia Caamal for providing the experimental animals.

\section{References}

Aguila, J., 2007. Bases nutricionales para el cultivo del pulpo Octopus maya. Universidad Nacional Autónoma de México, Posgrado en Ciencias del Mar y Limnología, pp. 1-76.

Aguila, J., Cuzon, G., Pascual, C., Domingues, P., Gaxiola, G., Sánchez, A., Maldonado, T., Rosas, C., 2007. The effects of fish hydrolysate (CPSP) level on Octopus maya (Voss and Solis) diet: Digestive enzyme activity, blood metabolites, and energy balance. Aquaculture 273, 641-655.

Akagi, S., Ohmori, S., 2004. Threonine is the best substrate for D-lactate formation in octopus tentacle. Amino Acids 26, 169-174.

Alcaraz, G., Espinoza, V., Vanegas, C., Carrara, X.C., 1999. Acute effect of ammonia and nitrite on respiration of Penaeus setiferus postlarvae under different oxygen levels. J. World Aquacult. Soc. 30, 98-106.

APHA, 1995. Standard Methods for the Examination of Water and Wastewater., 19 ed. American Public Health Association. add address and pages

Arzel, J., Metailler, R., Kerleguer, C., Le Delliou, H., Guillaume, J., 1995. The protein requirement of brown trout (Salmo trutta) fry. Aquaculture 130, 67-78.

Bligh, E.G., Dyer, W.J., 1959. A rapid method of total lipid extraction and purification. Can. J. Biochem. Physiol. 37, 911-931.

Boucaud-Camou, E., 1969. Etude histologique et histochimique de l'appareil digestif de Sepiola atlantica d'orbigny et Sepia officinalis. L. Bull. Soc. Linn. Normandie 9, 220-243. 
Boucaud-Camou, E., 1974. Localization d'activités enzymatiques impliquéz dans la digestion chez Sepia officinalis L. Arch. Zool. Exp. Gen. 115, 5-27.

Boucaud-Camou, E., Boucher-Rodoni, R., Mangold, K., 1976. Digestive absorption in Octopus vulgaris (Cephalopoda: Octopoda). J. Zool. 179, 261-271.

Boucaud-Camou, E., Boucher-Rodoni, R., 1983. Feeding and digestion in cephalopods. In: Saleuddin, A.S.M., Wilbur, K.M. (Eds.), The Mollusca. Academic Press, New York, pp. 149-187.

Bouche-Rodoni, R., 1975. Vitesse de digestion chez les cephalopodes Eledone cirrosa (Lamarck) et Illex illecebrosus (Lesueur). Cah. Biol. Mar. 16, 59-175.

Boucher-Rodoni, R., Boucaud-Camou, E., Mangold, K., 1987. Feeding and digestion. In: Boyle,P. (Ed.), Cephalopod Life Cycles. Academic Press, London, pp. 85-108.

Bradford, M.M., 1976. A refined and sensitive method for the quantitation of microgram quantities of protein utilizing the principle of protein-dye binding. Anal. Biochem. 72, 248.last page?

Brinker, A., Koppe, W., Rosch, R., 2005. Optimised effluent treatment by stabilised trout faeces. Aquaculture 249, 125-144.

Castro, B., DiMarco, F.P., DeRusha, R., Lee, P.G., 1993. The effects of surimi and pelleted diets on the laboratory survival, growth and feeding rate of the cuttlefish Sepia officinalis. J. J. Exp. Mar. Biol. Ecol. 70, 241-252.

Cho, C., Bureau, D., 2001. A review of diet formulation strategies and feeding systems to reduce excretory and feed wastes in aquaculture. Aquacult. Res. 32, 349-360.

Cuzon, G., Aquacop, 1998. Nutritional review of Penaeus stylirostris. Rev. Fish. Sci. 6, 129-141.

Dall, W., Smith, D.M., 1986. Oxygen consumption and ammonia-N excretion in fed and starved tiger prawns Penaeus esculentus Haswell. Aquaculture 55, 23-33.

Domingues, P., López, N., Muñoz, J.A., Maldonado, T., Gaxiola, G., Rosas, C., 2007. Effects of an artificial diet on growth and survival of the Yucatan octopus, Octopus maya. Aquacult. Int. 13, 1-9.

Dominy, W.G., Cody, J.J., Terpstra, J.H., Obaldo, L.G., Chai, M.K., Takamori, T.I., Larsen, B., Foster, I.P., 2004. A comparative study of the physical and biological properties of commerciallyavailable binders for shrimp feeds. J. Appl.Aquacult. 14, 1-14.

Dubois, M.K., Lilles, L.A., Hamilton, J.C., Rebers, P.A., Smith, F., 1965. Cholorimetric method for determination of sugars and related substances. Anal.. Chem. 28, 350-356.

Fujisawa, T., Akagi, S., Kawase, M., Yamamoto, M., Ohmori, S., 2005. d-Lactate metabolism in starved Octopus ocellatus. J. Exp. Zool. 303A, 489-496.

Gabaudan, J., 1987. Studies of nutrients ADC in sea bass (Dicentrarchus labrax). II. Effects of Na alginate on protein and lipid. Ifremer publication, Nutrition Series, 1-8.

Lucas, A., 1993. Bioénergétique Des Animaux Aquatiques. Masson, Paris. 347 pp

Morales, A., Cardenete, G., Sanz, A., Akharbach, H., de la Higuera, M., 1993. Influence of different binders on dietary availability of nutrients in rainbow trout. Colloq. INRA. (France). Paris. 34.

Obaldo, L.G., Divakaran, S., Tacon, A.G., 2002. Method for determining the physical stability of shrimp feeds in water. Aquacult. Res. 33, 369-377.

Pérez, M.C., López, D.A., Aguila, K., González, M.L., 2006. Feeding and growth in captivity of the octopus Enteroctopus megalocyathus. Aquacult. Res. 37, 550-555.

Perrin, A., Le Bihan, E., Koueta, N., 2004. Experimental study of enriched frozen diet on digestive enzymes and growth of juvenile cuttlefish Sepia officinalis L. (Mollusca Cephalopoda). J. Exp. Mar. Biol. Ecol. 311, 267-285.

Petza, D., Katsenavakis, S., Verriopoulus, G., 2006. Experimental evaluation of the energy balance in Octopus vulgaris, fed ad libitum on a high-lipid diet. Mar. Biol. 148, 827-832.

Regnault, M., 1979. Ammonia excretion of the sand-shrimp Crangon crangon (L.) during moult cycle. J. Comp. Physiol. 33, 199-204.

Rosas, C., Vanegas, C., Tabares, I., Ramirez, J., 1993. Energy balance of Callinectes rathbunae Contreras 1930 in floating cages in a tropical coastal lagoon. J. World Aquacult. Soc. 24, 71-79.

Rosas, C., Cuzon, G., Pascual, C., Gaxiola, G., López, N., Maldonado, T., Domingues, P., 2007. Energy balance of Octopus maya fed crab and artificial diet. Mar. Biol. 152, 371-378.

Storebakken, T., 1985. Binders in fish feeds. 1. Effect of alginate and guar gum on growth, digestibility, feed intake and passage through the gastrointestinal tract of rainbow trout. Aquaculture 47, 11-26.

Van Heukelem, W.F., 1976. Growth, bioenergetics and life span of Octopus cyanea and Octopus maya. PhD Thesis, Univ. Hawaii, pp. 1-224 
Villanueva, R., Riba, J., Ruíz-Capillas, C., González, A.V., Baeta, M., 2004. Amino acid composition of early stages of cephalopods and effects of amo acid dietary treatmets on Octopus vulgaris paralarvae. Aquaculture 242, 455-478.

Yamamoto, T., Akiyama, T., 1995. Effect of carboxymethylcellulose, alpha -starch, and wheat gluten incorporated in diets as binders on growth, feed efficiency, and digestive enzyme activity of fingerling Japanese flounder. Fisheries Sci. 61, 309-313.

Zar, J.H., 1974. Bioestatistical Analysis. Prentice Hall, Englewood Cliff. CA 545 pp 
Table 1. Energy balance of Octopus maya juveniles fed natural crab meat and crab paste bound with gelatin. Mean $\pm S$.E. Different letter means statisticall diferences between treatments at $P<0.05$ level.

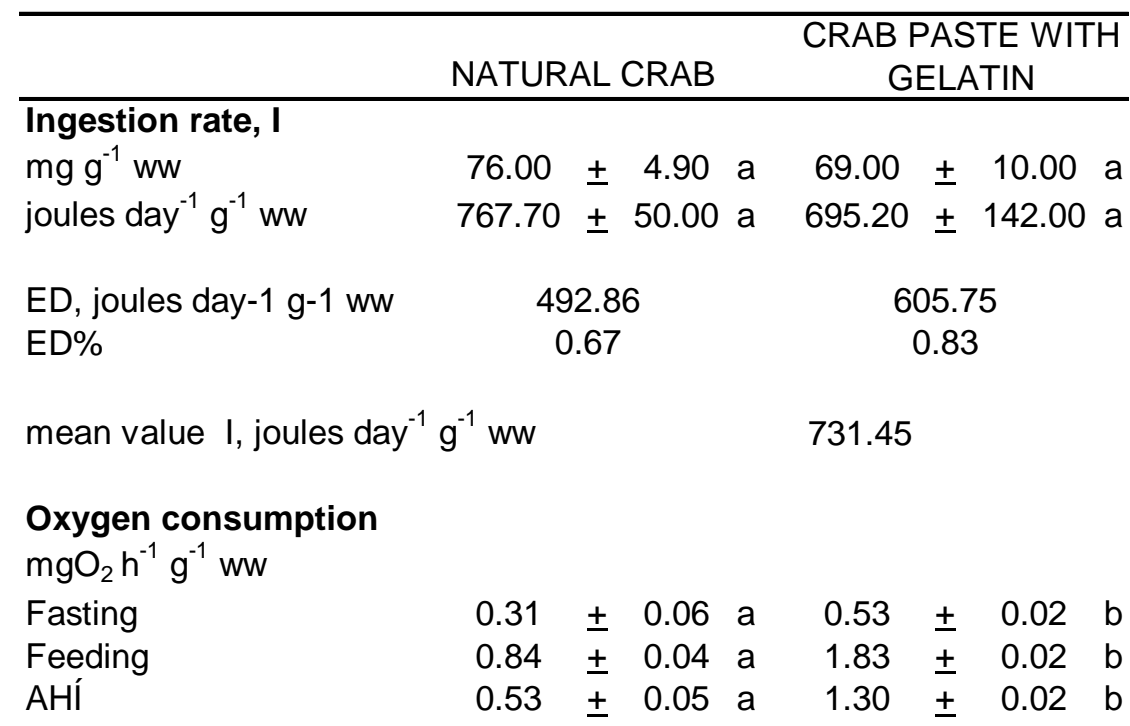

\section{Respiration, $\mathbf{R}$}

joules day $\mathrm{g}^{-1} \mathrm{ww}$

\begin{tabular}{|c|c|c|c|c|}
\hline & 101.96 & $\pm 19.73 \mathrm{a}$ & $174.32 \pm$ & 6.58 \\
\hline $\mathrm{AHI}$ & 7.58 & $0.72 \mathrm{a}$ & 18.59 & 0.29 \\
\hline tot, joules day ${ }^{-1} g^{-1} \mathrm{ww}$ & 109.54 & $\pm 10.22 \mathrm{a}$ & $192.91 \pm$ & 3.43 \\
\hline
\end{tabular}

\section{Ammonia Excretion}

$\mathrm{mgNH}_{3} \mathrm{~h}^{-1} \mathrm{~g}^{-1} \mathrm{ww}$

$\begin{array}{lllllllll}\text { Fasting } & 0.15 & \pm & 0.03 & \mathrm{a} & 0.19 & \pm & 0.01 & \mathrm{a} \\ \text { Feeding } & 0.34 & \pm & 0.31 & \mathrm{a} & 0.64 & \pm & 0.06 & \mathrm{~b} \\ \text { NEPA } & 0.19 & \pm & 0.08 & \mathrm{a} & 0.45 & \pm & 0.04 & \mathrm{~b}\end{array}$

\section{Energy lost, $\mathbf{U}$}

joules day $\mathrm{g}^{-1} \mathrm{ww}$

Urut

Unepa

$70.73 \pm 64.48$ a $85.69 \pm 8.03$ a

$3.90 \pm 1.64$ a $18.45 \pm 1.44 \mathrm{~b}$

Utotal, joules day ${ }^{-1} \mathrm{~g}^{-1} \mathrm{ww}$

$74.62 \pm 33.06$ a $104.14 \pm 4.73 \mathrm{~b}$

\section{$\mathrm{O}: \mathrm{N}$ ratio}

Fasting

Feeding

$$
\begin{array}{llllllll}
2.19 & \pm & 0.05 & \mathrm{a} & 2.96 & \pm & 0.02 & \mathrm{~b} \\
2.62 & \pm & 0.18 & \mathrm{a} & 3.03 & \pm & 0.04 & \mathrm{~b}
\end{array}
$$

\section{Production, $\mathbf{P}$}

Initial weight, $\mathbf{g}$

Final weight, $\mathrm{g}$

Days

Growth rate, mg/day

DGC, \% day ${ }^{-1}$

$P$, joules day ${ }^{-1} \mathrm{~g}^{-1} \mathrm{ww}$

$\begin{array}{cccccccc}0.73 & \pm & 0.06 & \mathrm{a} & 0.71 & \pm & 0.06 & \mathrm{a} \\ 1.03 & \pm & 0.08 & \mathrm{a} & 1.04 & \pm & 0.22 & \mathrm{a} \\ & 20 & & & & 20 & & \\ 15.00 & \pm & 1.35 & \mathrm{a} & 16.50 & \pm & 1.64 & \mathrm{a} \\ 1.72 & \pm & 0.18 & & 1.91 & \pm & 0.14 & \mathrm{a} \\ 294.00 & \pm & 26.46 & \mathrm{a} & 323.40 & \pm & 32.14 & \mathrm{a} \\ 1.81 & & & & & & & \end{array}$

Mean Value, $P$, joules day-1 g-1 uw 308.7 
Figures

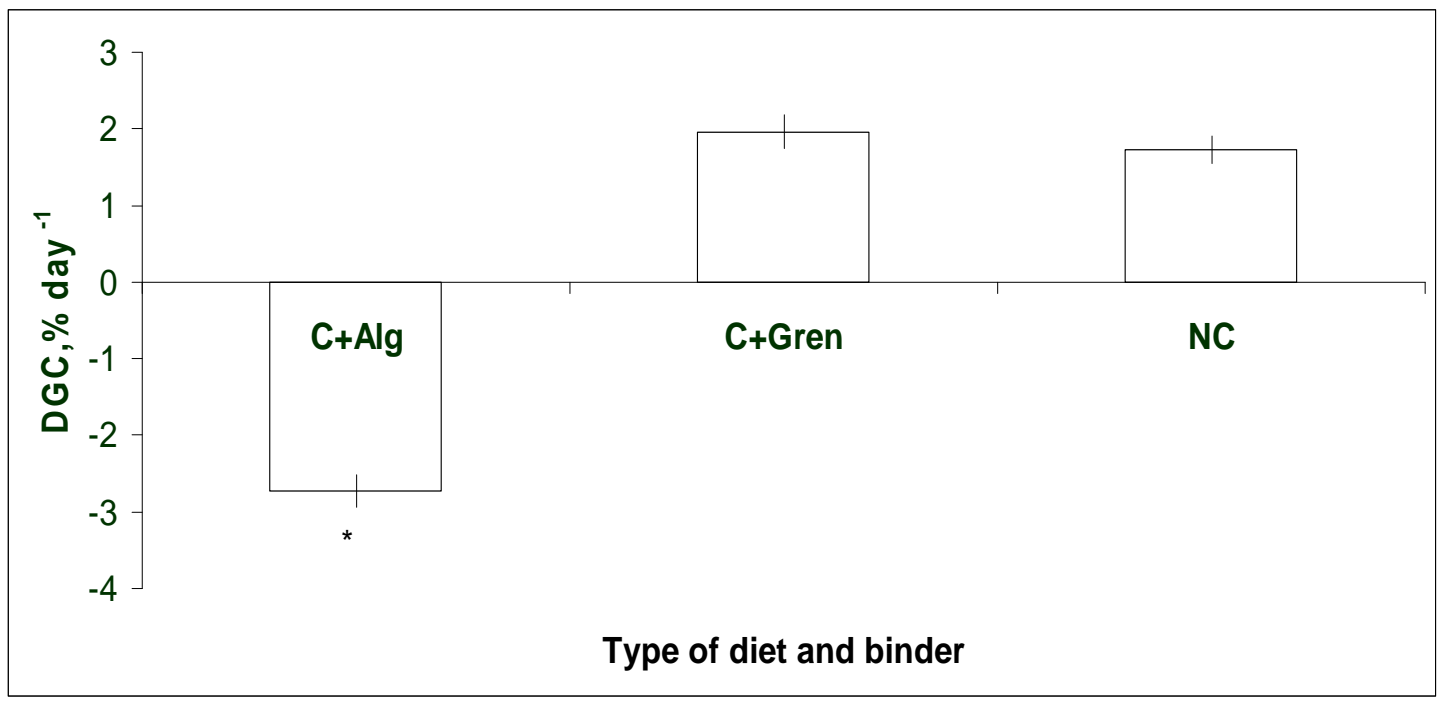

Fig. 1. Effect of type of binder on daily growth rate of Octopus maya juveniles. $\mathrm{C}+\mathrm{Alg}=\mathrm{Crab}+$ alginate $\mathrm{C}+$ Gelatin $=\mathrm{Crab}+$ gelatin; $\mathrm{NC}=$ Natural Crab. Mean $\pm \mathrm{S} . \mathrm{E}$. ${ }^{*}$ means statistical differences at $P<0.05$ ). 

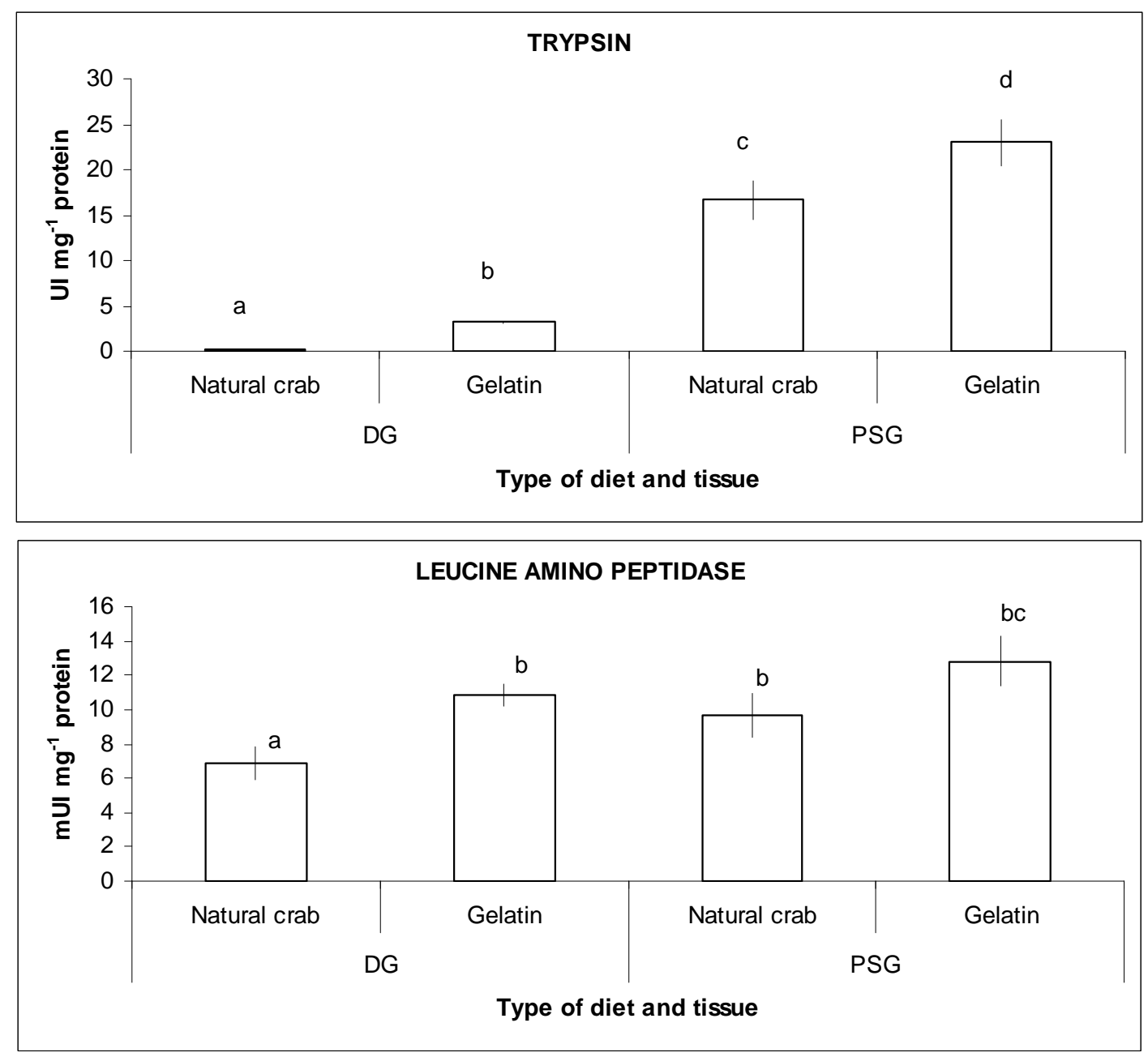

Fig. 2. Effect of type of binder on digestive enzyme activity of Octopus maya fed natural crab or bound gelatin crab paste. $\mathrm{DG}=$ digestive gland; $\mathrm{PSG}=$ posterior salivary glands. Mean $\pm \mathrm{S} . \mathrm{E}$. Different letters means statistical differences at $P<0.05$. 


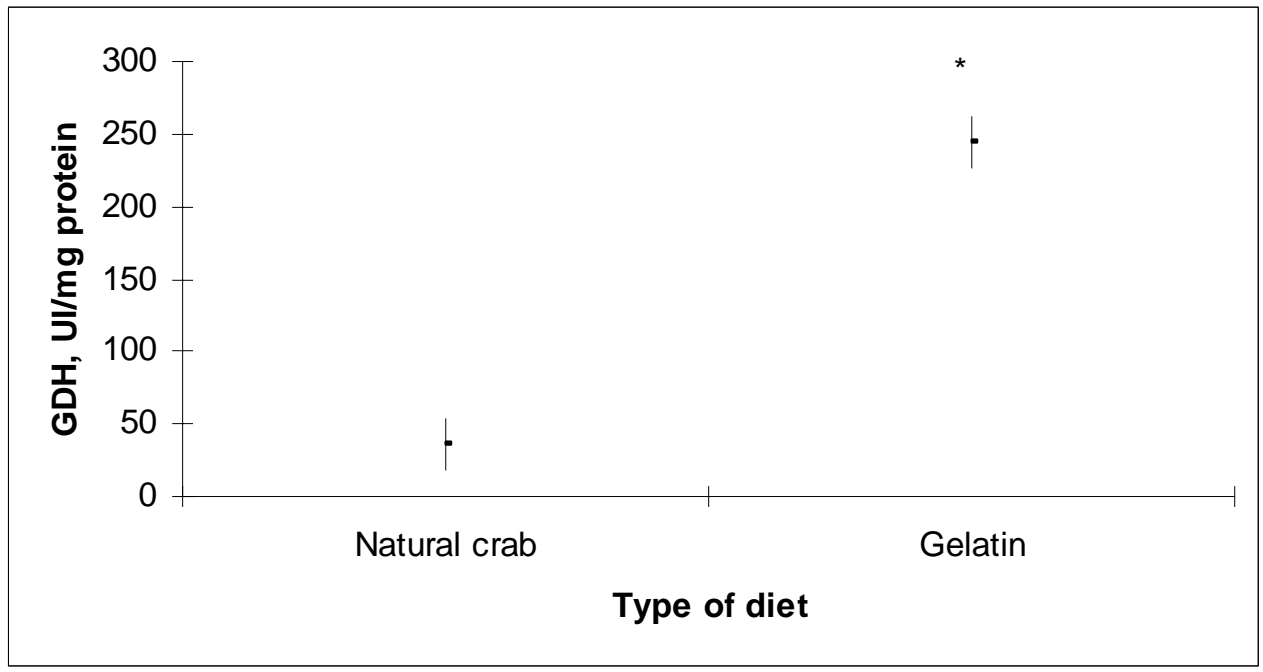

Fig. 3. Effect of diet composition on GDH activity. Mean \pm S.E. Asterisk indicates statistical differences $P<0.05$. 

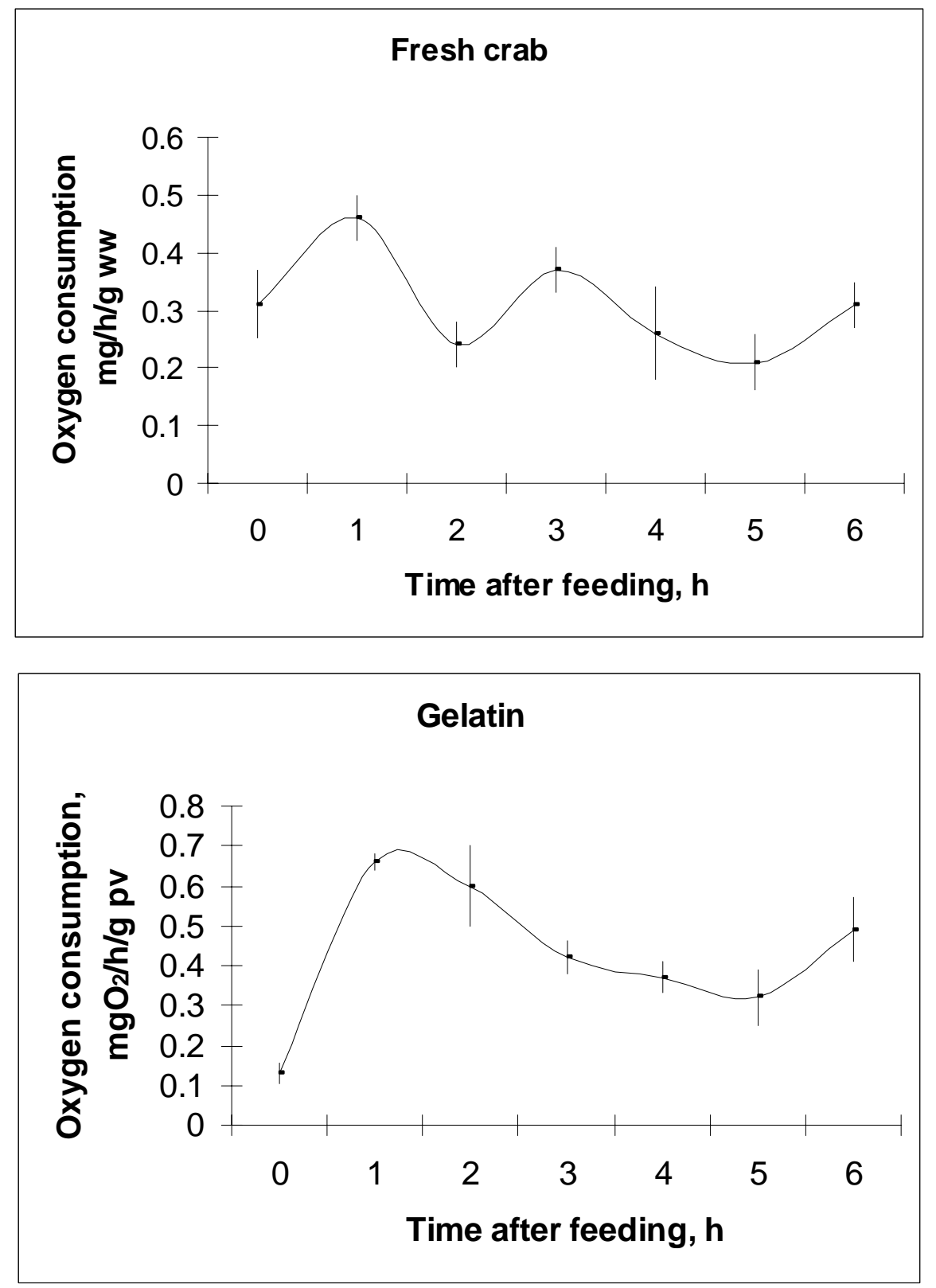

Fig. 4. Oxygen consumption during feeding of $O$. maya fed different types of binder. Mean \pm S.E. 

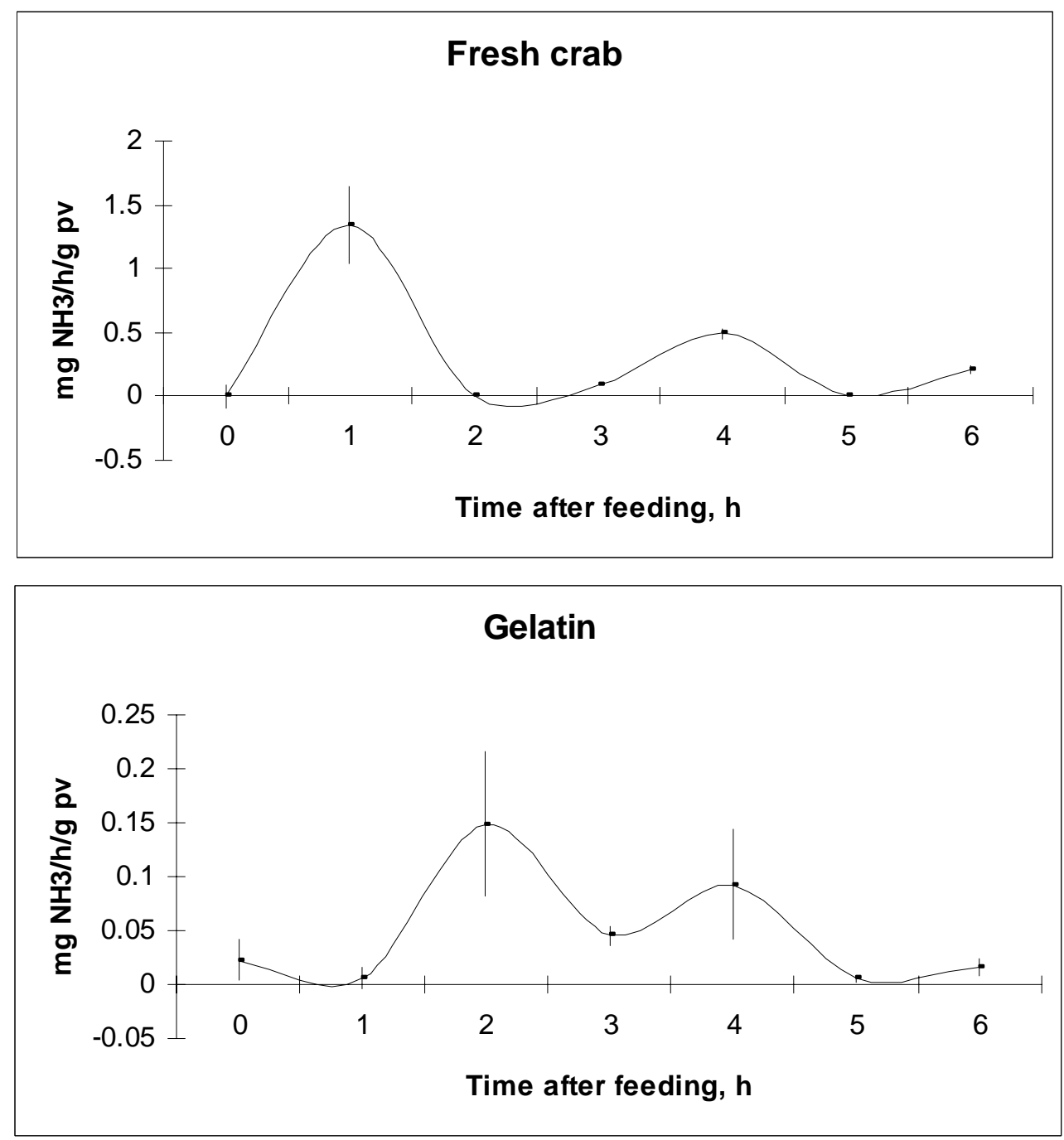

Fig. 5. Ammonia excretion during feeding of $O$. maya fed different types of binder. Mean \pm S.E. 


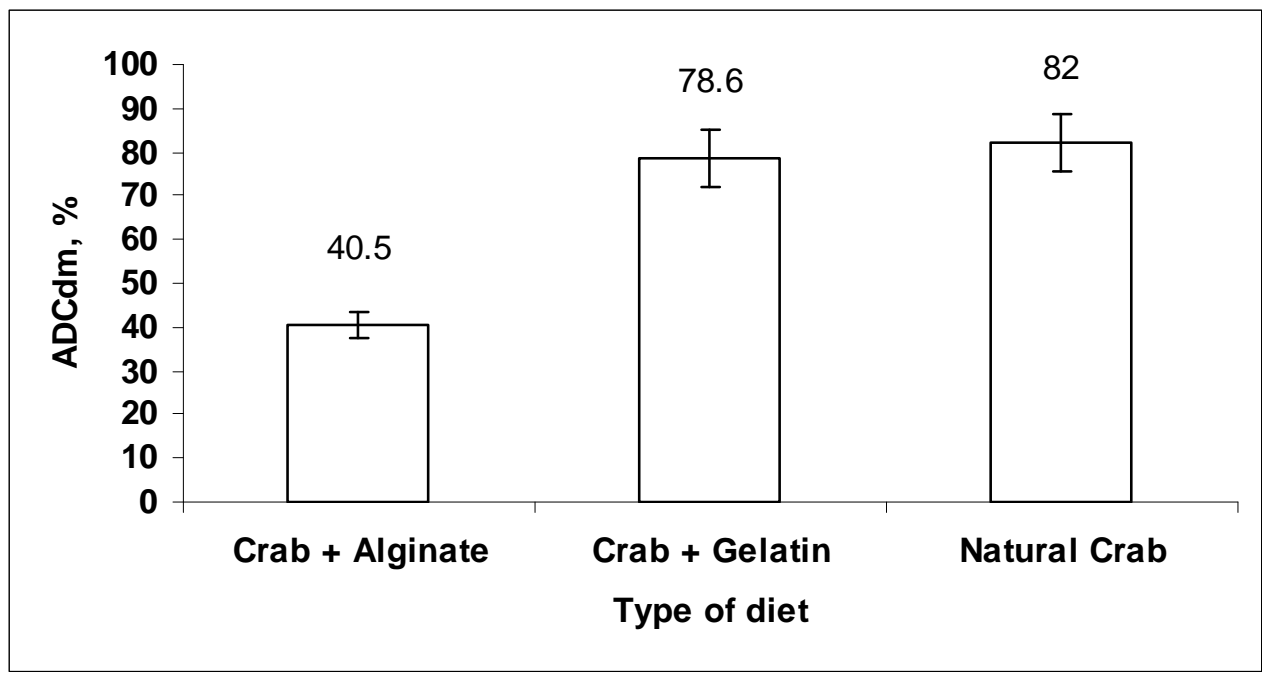

Fig. 6. $A D C_{D M}$ Apparent dry matter digestibility coefficient of alginate-bound crab paste or gelatin. Mean \pm S.E. 